\title{
The effect of spiroperidol on tonic immobility in domestic fowl
}

\author{
CHARLES W. HENNIG and BRIAN D. SPENCER \\ Salem College, Salem, West Virginia
}

\begin{abstract}
Six groups of 2.5-week-old chickens were injected with either distilled water, $1 \%$ lactic acid, or various dosages of spiroperidol $(.02, .2,2$, and $20 \mathrm{mg} / \mathrm{kg})$. The largest dose of this drug significantly reduced the general activity of the subjects. Spiroperidol also produced dose-dependent enhancement of tonic immobility durations, but had no apparent effect on the number of inductions required to elicit the immobility response. These results are discussed in terms of serotonergic and dopaminergic involvement with tonic immobility.
\end{abstract}

Tonic immobility (TI) is a naturally occurring response that is elicited in a wide variety of animals by a brief period of physical restraint. Initially, the animal struggles and attempts to escape, but these responses subside and are followed by a motionless, catatonic-like posture that may persist for periods ranging from a few seconds to several hours after release. During this time, the animal shows inhibition of movement, waxy flexibility, tremors of the extremities, hypertonicity of skeletal muscles, intermittent eye closure, decreased vocalization, mydriasis, and various physiological changes (Gallup, 1974). The response terminates abruptly and is often followed by escape reactions. Tonic immobility has been conceptualized as the terminal defense response in a sequential series of antipredator behaviors (Gallup, 1977; Ratner, 1967), but because of similarities in characteristics, TI has also been proposed as an animal model for catatonic and cataleptic states in humans (Gallup \& Maser, 1977).

A number of studies have investigated the neuropharmacology of the immobility response. Several researchers (Hughes, 1982; Thompson, Piroch, Fallen, \& Hatton, 1974) have proposed a cholinergic (ACh) inhibition system as the basis for tonic immobility, since various $\mathrm{ACh}$ agents such as scopolamine, atropine, and physostigmine have been shown to affect the immobility response. However, other investigators have favored a serotonergic (5-HT) control mechanism for tonic immobility. Wallnau and Gallup (1977) proposed a midbrain-raphe model of immobility duration, in which the inhibition of 5-HT raphe neurons was associated with enhanced immobility durations, while increases in raphe firing were correlated with shortened TI reactions. More

Portions of this paper were presented at the annual meeting of the West Virginia Academy of Science at Glenville, West Virginia, in April 1983. Thanks are expressed to Andrea J. Small of Janssen Pharmaceutica, Inc., for her generosity in supplying spiroperidol. Reprint requests should be sent to Charles W. Hennig, Psychology Department, Salem College, Salem, West Virginia 26426. recently, there has been a revision of this serotonergic model of TI, with a shift in emphasis to the postsynaptic consequences of 5-HT manipulations (Wallnau, 1981; Wallnau, Bordash, \& Corso, 1981a). There has also been support for the involvement of the catecholamines with the immobility response. Both epinephrine and norepinephrine are known to potentiate TI duration (Thompson \& Joseph, 1978; Thompson, Scuderi, \& Boren, 1977), indicating that the adrenergic neurochemical system can influence tonic immobility. Hennig, Dunlap, Harston, and MacPhee (1980) found that drugs that stimulated alpha $a_{2}$ adrenoceptors potentiated TI duration, whereas drugs that stimulated alpha $_{1}$ adrenoceptors tended to shorten the immobility response. Other findings have also implicated the dopaminergic (DA) system in tonic immobility. Ettinger and Thompson (1978) demonstrated that injections of L-DOPA, a precursor of DA, increased durations of tonic immobility in chickens, while Wallnau, Carnrike, and Dewey (1979) showed that the DA blocker haloperidol enhanced TI durations and that apomorphine, a DA receptor agonist, attenuated immobility durations. All of this research indicates that several different neurochemical systems are involved with the production of the TI response and suggests that future studies on the neuropharmacology of this behavior should examine possible interactions between some of these systems.

One such interaction may occur between serotonergic and dopaminergic systems. There is ample evidence to suggest the existence of parallel 5-HT and DA neuron pathways in the striatal regions of the mammalian brain (Davies \& Tongroach, 1978) and homologous areas of the avian brain (Juorio \& Vogt, 1967), which are known to participate in psychomotor functions such as catalepsy. Furthermore, the putative 5-HT agonist quipazine has been shown to block the cataleptic state produced by haloperidol, a well-known DA antagonist (Grabowska, Antkiewicz, \& Michaluk, 1974), and 5-HT depletion by p-chlorophenylalanine (PCPA) or raphe lesions has been found to block such haloperidol-induced catalepsy (Kostowski, Gumulka, \& Czlonkowski, 1972). In addi- 
tion, Wallnau (1980) reported that quipazine blocked the haloperidol enhancement of tonic immobility in chickens. Fenfluramine, another 5-HT receptor agonist, also reversed the potentiation of TI duration produced by haloperidol, while DA receptor stimulation by apomorphine prevented the enhancement of immobility duration caused by tryptophan, a precursor of 5-HT (Wallnau, Bordash, \& Corso, 1981b). These findings led Wallnau and associates to suggest that 5-HT and DA neurochemical systems may in teract to play a role in the tonic immobility response. They also serve to remind researchers that the specificity of a drug's action on a certain system is less than absolute.

However, before Wallnau's hypothesis can be accepted or the interaction between the 5-HT and DA systems underlying tonic immobility can be understood fully, more data about drugs that can affect both the immobility response and these two neurochemical systems must be gathered. One such drug may be spiroperidol. This substance is known to be a dopamine antagonist and can produce catelepsy in rats (Baez, Burt, Granneman, \& Shanklin, 1979). In addition, spiroperidol has also been suggested as a powerful antagonist for the recently discovered $5-\mathrm{HT}_{2}$ type of serotonin receptor (Peroutka \& Snyder, 1979). Therefore, the present study attempted to examine the effects of spiroperidol on tonic immobility in chickens. Domestic fowl were used as subjects because they display a pronounced immobility response that is easily induced and quantified.

\section{METHOD}

\section{Subjects}

The subjects were 54 straight-run Production Red chickens (Gallus gallus) obtained from a commercial hatchery (Welp, Inc.) at 1 day of age. These birds were group-reared in commercial brooders and provided with Purina Chick Starter and water at all times. The photoperiod in effect throughout the study consisted of $12 \mathrm{~h}$ of light (6 a.m. to $6 \mathrm{p} . \mathrm{m}$.). In order to reduce the effects of taming on TI baseline, human exposure was limited to daily feeding and maintenance.

\section{Apparatus and Procedure}

Testing was conducted when the animals were 15 days of age. On the day of the experiment, the birds were assigned randomly to one of six groups of nine animals each. These birds were weighed and given intraperitoneal (ip) injections of $2 \mathrm{ml} / \mathrm{kg}$ body weight of the following substances. Four groups received ip injections of $.02, .2,2$, or $20 \mathrm{mg} / \mathrm{kg}$ of spiroperidol (Janssen) dissolved in $1 \%$ lactic acid. The remaining two groups received equivalent volumes of either $1 \%$ lactic acid or distilled water. Then the animals were placed in separate cardboard boxes and were transported to individual testing rooms. Ten minutes later, each bird was placed on an open table and its behavior was observed for $15 \mathrm{sec}$. If the animal stood up or moved around during this time, it was noted as being active, but if it sat quietly in one place, the bird was considered nonactive. Then the animal was restrained on its right side for $15 \mathrm{sec}$, at which time the experimenter's hands were gently withdrawn and a stopwatch was activated. Immobility durations were timed from the moment of release until the bird showed a righting response or until a maximum of $3,600 \mathrm{sec}$ had elapsed. Any subjects that failed to remain immobile for at least $5 \mathrm{sec}$ were given up to five successive inductions in an attempt to elicit immobility, with a $30-\sec$ intertrial interval between attempts. Any animals that failed to exhibit TI after five inductions were given duration scores of zero. Testing was performed by experimenters who were unaware of the treatments that the birds had received. To preclude any confounding effect of periodicity, testing was staggered over the day, with a comparable number of birds from each group being tested at different times throughout the day.

\section{RESULTS}

As shown in Table 1, spiroperidol produced dosedependent reductions in the general activity of the subjects. This was especially true for those chickens that received the largest dosage of the drug. An analysis of variance (ANOVA) performed on the data revealed a significant overall difference between groups on the number of animals that were active $[\mathrm{F}(5,48)=3.96$, $\mathrm{p}<.005$ ]. However, a subsequent Dunnett's test that compared group means with the distilled water control found that only the largest dosage of spiroperidol produced a significant decrease in general activity [ $t(48)=$ $3.70, p<.01]$. The number of inductions required to produce tonic immobility were also shown in Table 1, but an ANOVA performed on these data failed to find any reliable effect by spiroperidol on this measure of susceptibility to the immobility response. The mean durations of immobility for the groups of subjects in this study are shown in the lower part of Table 1 . As can be seen, even the smallest dosage of spiroperidol $(.02 \mathrm{mg} / \mathrm{kg})$ more than doubled the mean duration of the response, while larger doses of this drug produced progressively greater increases in TI duration. Due to extreme skewness in the data, $\log _{10}(x+1)$ transformations were performed on all scores before statistical analysis, which

Table 1

Activity State Before Immobility, Mean Number of Inductions Required to Produce Immobility, and Mean Durations of Immobility (in Seconds) as a Function of Dosages of Spiroperidol

\begin{tabular}{|c|c|c|c|c|c|c|}
\hline \multirow[b]{2}{*}{ Dependent Variables } & \multicolumn{2}{|c|}{ Control Groups ( $n=9 /$ group) } & \multicolumn{4}{|c|}{ Spiroperidol Groups (n = 9/group) } \\
\hline & Water & Lactic Acid & $.02 \mathrm{mg} / \mathrm{kg}$ & $.2 \mathrm{mg} / \mathrm{kg}$ & $2 \mathrm{mg} / \mathrm{kg}$ & $20 \mathrm{mg} / \mathrm{kg}$ \\
\hline Active & 7 & 7 & 5 & 5 & 3 & $0 * *$ \\
\hline Not Active & 2 & 2 & 4 & 4 & 6 & 9 \\
\hline Mean Number of Inductions & 1.11 & 1.11 & 1.00 & 1.11 & 1.33 & 1.00 \\
\hline Mean Durations of Immobility & 314.9 & 140.0 & $754.6 *$ & $1122.1^{*}$ & $1852.9 * *$ & $2668.8 * *$ \\
\hline
\end{tabular}

Note-Differences from the water control were assessed statistically using the Dunnett test. $\quad{ }^{*} p<.05 . \quad{ }^{* *} p<.01$. 
resulted in a normalization of the data. An ANOVA performed on the transformed scores in this experiment revealed a significant overall difference between groups for immobility durations $[\mathrm{F}(5,48)=11.92$, $\mathrm{p}<.001]$. A subsequent Dunnett's test that compared group means with the distilled water control found that all of the spiroperidol dosages produced mean durations of immobility that were significantly greater than that of the control $[\mathrm{t}(48)=2.37, \mathrm{p}<.05 ; \mathrm{t}(48)=2.61, \mathrm{p}<.05$; $\mathrm{t}(48)=4.66, \mathrm{p}<.01 ; \mathrm{t}(48)=5.76, \mathrm{p}<.01$ (for the smallest to the largest dosages of spiroperidol, respectively)]. Only the lactic acid group failed to differ significantly from the distilled water control group.

\section{DISCUSSION}

Gallup and Maser (1977) noted a number of behavioral similarities between tonic immobility and some forms of catalepsy. There have also been reports of neurochemical semblances for these two phenomena. For example, haloperidol, a well-known DA receptor blocker, produced catalepsy in rats (Costall, Fortune, Naylor, Marsden, \& Pycock, 1975) and enhanced TI durations in chickens (Wallnau et al., 1979). Spiroperidol, another DA antagonist, also produced catalepsy in rats (Baez et al., 1979). In addition, the present study demonstrated that spiroperidol caused dose-dependent increases in TI durations in chickens, although it had no apparent effect on the number of inductions required to elicit this response. Moreover, the largest dosage of spiroperidol $(20 \mathrm{mg} / \mathrm{kg})$ drastically reduced the general activity of the subjects even before immobility occurred. This suggests that cataleptic behavior in chickens may be produced by high dosages of spiroperidol. Thus, it appears that the blockade of postsynaptic DA receptors by these two DA antagonists can produce catalepsy and enhance TI durations. On the other hand, stimulation of DA receptors by apomorphine attenuated the duration of tonic immobility (Wallnau et al., 1979). Taken together, these findings support the involvement of the DA system with tonic immobility and some forms of catalepsy.

However, numerous studies have shown that manipulations of the serotonergic neurochemical system (e.g., precursor loading, 5-HT depletion, reuptake inhibition, monoamine oxidase inhibition, promotion of 5-HT release, receptor stimulation, and receptor blockade) produce significant effects on the tonic immobility response (for reviews, see Boren, Gallup, Suarez, Wallnau, \& Gagliardi, 1979; Wallnau et al., 1981a; and Wallnau \& Gallup, 1977). Wallnau and Gallup (1977) proposed a midbrain-raphe model to explain the effects of serotonergic drugs on the immobility response, but more recent findings suggested that the postsynaptic results of 5-HT manipulations provided better predictions for serotonergic effects on tonic immobility (Boren et al., 1979; Wallnau et al., 1981a). In an attempt to integrate the data from both serotonergic and dopaminergic drug studies on tonic immobility, Wallnau et al. (1981b) suggested the possibility of an interaction between the 5-HT and DA mechanisms thought to be responsible for TI and other related cataleptic behaviors. Such a hypothesis was consistent with past research that had demonstrated 5-HT involvement with the catalepsy and tonic immobility generated by DA antagonists (Grabowska et al., 1974; Kostowski et al., 1972; Wallnau, 1980; Wallnau et al., $1981 \mathrm{~b}$ ) and with the potentiation of TI duration produced by spiroperidol, another DA blocker, in the present study. Nevertheless, there may be an alternative explanation for these results that does not require DA involvement with the immobility response.

Peroutka and Snyder (1979) reported that they found two different types of serotonin receptors in the mammalian central nervous system, which they labeled as $5-\mathrm{HT}_{1}$ and $5-\mathrm{HT}_{2}$ receptors. The $5-\mathrm{HT}_{1}$ receptors, which seem inhibitory in nature, are highly sensitive to even small amounts of serotonin, while the $5-\mathrm{HT}_{2}$ receptors act in an excitatory manner and are stimulated only by very large amounts of serotonin. However, the latter receptors are very sensitive to spiroperidol, which blocks serotonergic action at 5- $\mathrm{HT}_{2}$ sites. Such dual receptor mechanisms may explain the biphasic effects of 5-HT on tonicimmobility duration (Hennig, 1980) and the paradoxical attenuation of TI duration with the combined administration of tryptophan and pargyline (Boren et al., 1979). Hennig (1980) found that small dosages of serotonin increased TI duration in chickens, whereas large doses of serotonin attenuated the response. In a somewhat similar manner, Boren et al. (1979) reported that injections of either tryptophan or pargyline increased TI duration when given alone, but found that combined administration of these drugs reduced immobility duration. The former manipulation using either drug probably increases serotonin levels slightly, whereas the latter condition using combined administration of these drugs probably produces very large increases in serotonin levels. Any explanation of these results that relies on the concept of two different types of 5-HT receptors should predict that manipulations that produce small increases in serotonin levels would stimulate the inhibitory $5-\mathrm{HT}_{1}$ receptors and potentiate TI duration and that manipulations that greatly increase serotonin levels would stimulate the excitatory $5-\mathrm{HT}_{2}$ receptors and produce a decrease in duration of immobility. The data from the latter two studies seem to fit these predictions quite well. Moreover, Boren et al. (1979) demonstrated that the attenuation of TI duration produced by the combined administration of tryptophan and pargyline was analogous to a stereotyped behavioral syndrome in rats that consisted of resting tremor, rigidity, head shaking, reciprocal forepaw treading, hindlimb abduction, straub tail, and hyperactivity, which was seen after similar drug treatments designed to increase 5-HT levels. Spiroperidol blocked the occurrence of this syndrome in rats (Jacobs, 1974) and also potentiated TI duration in chickens in the present study. These findings suggested that both the stereotyped behavioral syndrome in rats and the reduced TI durations in chickens were produced by the stimulation of 5- $\mathrm{HT}_{2}$ receptors, since they were blocked by spiroperidol, which has been reported to bind selectively with 5- $\mathrm{HT}_{2}$ receptors (Peroutka \& Snyder, 1979). Peroutka and Snyder also reported that haloperidol had a similar, although less potent, sensitivity for $5-\mathrm{HT}_{2}$ receptors. Taken together, all these data suggest a possible serotonergic explanation for the effects of spiroperidol and haloperidol on tonic immobility and catalepsy, but even this is not the entire answer.

Researchers should remember that the specificity of any drug is less than absolute and that the final determination as to which neurochemical system a drug such as spiroperidol acts upon when influencing tonic immobility or catalepsy may depend on some as yet unknown factors. One such variable might involve the specific brain structures that affect the immobility response. For example, several studies have indicated that the cerebral cortex and hippocampus inhibit tonic immobility duration in mammals (Teschke, Maser, \& Gallup, 1975; Woodruff, Hatton, $\&$ Meyer, 1975). Creese and Snyder (1978) reported that spiroperidol binds more effectively with 5 -HT than DA receptors in the cerebral cortex and hippocampus, but it binds more strongly with DA than 5-HT receptors in the striatum. Therefore, the site of action for a drug may actually determine which neurochemical system it acts upon. However, much more additional research is still needed before any specific explanations can be made about how a drug such as spiroperidol influences the immobility response.

\section{REFERENCES}

Baez, L. A., Burt, D. K., Granneman, J., \& Shanklin, C. Dopaminergic antagonism and catalepsy in the developing rat. European Journal of Pharmacology, 1979, 54, 15-20.

Boren, J. L., Gallup, G. G., JR., Suarez, S. D., Wallnau, 
L. B., \&GAGLiardi,G. J. Pargyline and tryptophan enhancement of tonic immobility: Paradoxical attenuation with combined administration. Pharmacology, Biochemistry and Behavior, 1979, 11, 17-22.

Costall, B., Fortune, D. H., Naylor, R. J., Marsden, C. D., \& Pycock, C. Serotonergic involvement with neuroleptic catalepsy. Neuropharmacology, 1975, 14, 859-868.

Creese, I., \& SNyder, S. H. 3H-spiroperidol labels serotonin receptors in rat cerebral cortex and hippocampus. European Journal of Pharmacology, 1978, 49, 201-202.

Davies, J., \& TongroACH, P. Neuropharmacological studies on the nigro-striatal and raphe-striatal system in the rat. European Journal of Pharmacology, 1978, 51, 91-100.

EtTinger, R. H., \& Thompson, R. W. The role of dopaminergic systems in the mediation of tonic immobility (animal hypnosis) in chickens. Bulletin of the Psychonomic Society, 1978, 12, 301-302.

Gallup, G. G., JR. Animal hypnosis: Factual status of a fictional concept. Psychological Bulletin, 1974, 81, 836-853.

GalluP, G. G., JR. Tonic immobility: The role of fear and predation. Psychological Record, 1977, 27, 41-61.

Gallup, G. G., Jr., \& Maser, J. D. Tonic immobility: Evolutionary underpinnings of human catalepsy. In J. D. Maser \& M. E. P. Seligman (Eds.), Psychopathology: Experimental models. San Francisco, Calif: Freeman, 1977.

Grabowska, M., Antkiewicz, L., \& Michaluk, J. A possible interaction of quipazine with central dopamine structures. Journal of Pharmacy and Pharmacology, 1974, 26, 74-76.

Hennig, C. W. Biphasic effects of serotonin on tonic immobility in domestic fowl. Pharmacology, Biochemistry and Behavior, $1980,12,519-523$.

Hennig, C. W., Dunlap, W. P., Harston, C. T., \& MacPhee, A. A. Tonic immobility and the alpha-adrenergic system in chickens. Physiology \& Behavior, 1980, 24, 21-25.

Hughes, R. A. Anticholinergic drugs, blood-brain-barrier and tonic immobility in chickens. Physiology \& Behavior, 1982, 29, 67-71.

JACOBS, B. L. Effect of two dopamine receptor blockers on a serontonin-mediated behavioral syndrome in rats. European Journal of Pharmacology, 1974, 27, 363-366.

Juorio, A. V., \& Vogt, M. Monoamines and their metabolites in the avian brain. Journal of Physiology, 1967, 189, 489-518.

Kostowski, W., Gumulka, W., \& Czlonkowski, A. Reduced cataleptogenic effects of some neuroleptics in rats with lesioned midbrain raphe and treated with p-chlorophenylalanine. Brain Research, 1972, 48, 443-446.

Peroutka, S. J., \& Snyder, S. H. Multiple serotonin receptors:
Differential binding of $\left[{ }^{3} \mathrm{H}\right]$ 5-hydroxytryptamine, $\left[{ }^{3} \mathrm{H}\right]$ lysergic acid diethylamide and $\left[{ }^{3} \mathrm{H}\right]$ spiroperidol. Molecular Pharmacology, 1979, 16, 687-699.

RATNER, S. C. Comparative aspects of hypnosis. In J. E. Gordon (Ed.), Handbook of clinical and experimental hypnosis. New York: Macmillan, 1967.

Teschke, E. J., Maser, J. D., \& Gallup, G. G., Jr. Cortical involvement in tonic immobility ("animal hypnosis"): Effect of spreading cortical depression. Behavioral Biology, 1975, 13, 139-143.

Thompson, R. W., \& Joseph, S. The effect of norepinephrine on tonic immobility in chickens. Bulletin of the Psychonomic Society, 1978, 12, 123-124.

Thompson, R. W., Piroch, J., Fallen, D., \& hatton, D. A central cholinergic inhibitory system as a basis for tonic immobility (animal hypnosis) in chickens. Journal of Comparative and Physiological Psychology, 1974, 87, 507-512.

Thompson, R. W., Scuderi, R., \& Boren, J. The effect of epinephrine on tonic immobility (animal hypnosis) in chickens. Bulletin of the Psychonomic Society, 1977, 9, 409-410.

Wallnau, L. B. Tonic immobility in domestic fowl: Anticataleptic effects of quipazine. Pharmacology, Biochemistry and Behavior, 1980, 12, 347-352.

WallnaU, L. B. The effects of quipazine, fenfluramine and apomorphine on the morphine potentiation of tonic immobility. Pharmacology, Biochemistry and Behavior, 1981, 15, 895-901.

Wallnau, L. B., Bordash, G. D., \& Corso, P., Jr. The effects of tryptophan and manipulations of serotonergic receptors on tonic immobility in chickens. Pharmacology, Biochemistry and Behavior, 1981, 14, 463-468. (a)

Wallnau, L. B., Bordash, G. D., \& Corso, P., Jr. Tonic immobility in domestic fowl: Possible interaction of serotonergic and dopaminergic mechanisms. Pharmacology, Biochemistry and Behavior, 1981, 14, 469-473. (b)

Wallnau, L. B., Carnrike, C. L., Jr., \& Dewey, G. I. Tonic immobility: Effects of dopamine receptor blockade and stimulation. Pharmacology, Biochemistry and Behavior, 1979, 10, 177-181.

Wallnau, L. B., \& Gallup, G. G., JR. A serotonergic, midbrainraphe model of tonic immobility. Biobehavioral Reviews, 1977, 1, 35-43.

Woodruff, M. L., Hatton, D. C., \& Meyer, M. E. Hippocampal ablation prolongs immobility response in rabbits (Oryctolagus cuniculus). Journal of Comparative and Physiological Psychology, 1975, 88, 329-334.

(Manuscript received for publication June 3, 1983.) 